\title{
Konsep Diri Remaja Cina Benteng (Studi Komunikasi Pada Remaja Cina Benteng di Tangerang)
}

\author{
Sheren Millennia, Suzy Azeharie \\ sherrenmillenia100@gmail.com,suzya@fikom.untar.ac.id
}

Fakultas Ilmu Komunikasi Universitas Tarumanagara

\begin{abstract}
Indonesia is a plural country because it has a variety of ethnicities, languages, religions. One of the ethnic groups in Indonesia is Benteng Chinese who have lived for a long time in Tangerang. Each ethnic group has its own identity or uniqueness that differentiates it from other ethnicities. Benteng Chinese society consists of various groups, one of which is a teenager. One of the most important periods in this phase of human life occurs in adolescence. During this period, a teenager's mental development and growth process occurs to form an identity that will describe his self-concept. Every teenager has a different self-concept. Parents are the biggest factor in the formation of adolescent self-concept. Imitation also affects self-concept. The purpose of this study was to describe the self-concept of Benteng Chinese Youth and what factors influence the self-concept of Benteng Chinese youths. In examining this research the writer uses concepts and theories, namely selfconcept, imitation, adolescence, and Cina Benteng. This research uses a qualitative approach with a case study method. The research data was obtained through interviews with two key informants and two supporting informants, as well as a literature study. The results showed that the self-concept possessed by Chinese Benteng youths varied physically, socially, and psychologically. And the factor that most influences the formation of adolescent self-concept is parents. adolescence, and Cina Benteng. This research uses a qualitative approach with a case study method. The research data was obtained through interviews with two key informants and two supporting informants, as well as a literature study. The results showed that the self-concept possessed by Chinese Benteng youths varied physically, socially, and psychologically. And the factor that most influences the formation of adolescent self-concept is parents. adolescence, and Cina Benteng. This research uses a qualitative approach with a case study method. The research data was obtained through interviews with two key informants and two supporting informants, as well as a literature study. The results showed that the self-concept possessed by Chinese Benteng youths varied physically, socially, and psychologically. And the factor that most influences the formation of adolescent self-concept is parents.
\end{abstract}

Keywords: adolescence, benteng chinese, self-concept

\begin{abstract}
Abstrak
Indonesia merupakan negara majemuk karena memiliki beragam suku, etnis, bahasa, agama. Salah satu etnis yang ada di Indonesia adalah Cina Benteng yang sudah menetap lama di Tangerang. Setiap etnis memiliki identitas atau keunikan masing-masing yang membedakan dengan etnis lainnya. Masyarakat Cina Benteng terdiri dari berbagai kalangan, salah satunya remaja. Salah satu periode terpenting dalam fase kehidupan manusia terjadi pada masa remaja. Pada masa ini terjadi proses perkembangan dan pertumbuhan mental seorang remaja sehingga membentuk jati diri yang akan menggambarkan konsep dirinya. Setiap remaja memiliki konsep diri yang berbeda-beda. Orang tua merupakan faktor terbesar terbentuknya konsep diri remaja. Imitasi juga berpengaruh terhadap konsep diri. Tujuan dari penelitian ini adalah untuk mengetahui gambaran konsep diri Remaja Cina Benteng dan faktor apa saja
\end{abstract}


yang mempengaruhi terbentuknya konsep diri remaja Cina Benteng. Dalam mengkaji penelitian ini penulis menggunakan konsep dan teori yaitu konsep diri, imitasi, remaja, dan Cina Benteng. Penelitian ini menggunakan pendekatan kualitatif dengan metode studi kasus. Data penelitian diperoleh melalui wawancara terhadap dua key informan dan dua informan pendukung, serta studi kepustakaan. Hasil penelitian menunjukkan bahwa konsep diri yang dimiliki remaja Cina Benteng berbeda-beda secara fisik, sosial, maupun psikologis. Faktor yang paling berpengaruh terhadap pembentukan konsep diri remaja adalah orang tua.

Kata Kunci: cina benteng, konsep diri, remaja

\section{Pendahuluan}

Salah satu fase terpenting pada fase kehidupan manusia terjadi pada fase remaja. Kata remaja menurut Chaplin merujuk masa peralihan dari pubertas menuju dewasa (Hendriyani et al., 2013:27). Pada periode ini terjadi proses perkembangan dan pertumbuhan mental seseorang sehingga membentuk jati diri yang akan menggambarkan mengenai dirinya. Pencarian jati diri seseorang dipengaruhi oleh pemikiran dari orang tersebut saat berinteraksi dengan lingkungan sekitarnya sehingga membentuk konsep diri.

Konsep diri menurut William H. Fitts adalah sebuah gambaran dalam bentuk rangkaian dari hasil berinteraksi dengan seseorang dan kemudian mempengaruhi perilaku yang didasari oleh dimensi internal dan eksternal (Gumulya et al., 2013:52). Sementara menurut Jalaludin Rakhmat, konsep diri dapat dilihat dari aspek psikologis, fisik, dan sosial (Priyastutik et al., 2019:3).

Indonesia merupakan negara majemuk karena memiliki beragam suku, etnis, bahasa, agama, dan ras. Salah satu etnis yang ada di Indonesia adalah etnis Cina yang masuk ke dalam posisi ke 18 sebagai etnis terbesar di Indonesia. Berdasarkan data Sensus Penduduk pada tahun 2010, jumlah masyarakat Indonesia keturunan Cina adalah 2,83 juta jiwa atau kurang lebih 1,2 persen dari jumlah seluruh penduduk Indonesia (https://databoks.katadata.co.id/datapublish/2017/01/28/283-persen penduduk-indonesia-adalah-etnis-cina diakses pada tanggal 1 Oktober 2020 pukul 22.03 WIB).

Cina Benteng merupakan salah satu etnis Cina yang ada di daerah Tangerang. Istilah Cina Benteng berawal pada berdirinya sebuah Benteng Makasar yang berada di pinggir Sungai Cisadane Kota Tangerang, Kecamatan Tangerang, Kelurahan Sukasari yang sudah ada dari zaman Belanda. Etnis Cina Benteng merupakan salah satu etnis yang sudah menetap lama di wilayah Tangerang (Anisa et al., 2012:95).

Rumusan masalah dari penelitian ini adalah bagaimana gambaran konsep diri remaja Cina Benteng dan faktor apa yang mempengaruhi terbentuknya remaja Cina Benteng. Penulis tertarik untuk meneliti konsep diri remaja Cina Benteng karena ingin mengetahui bagaimana konsep diri remaja keturunan etnis Cina Benteng dan juga ingin mengetahui faktor apa saja yang mempengaruhi terbentuknya konsep diri remaja Cina Benteng. Alasan lainnya adalah karena belum pernah ada yang meneliti mengenai konsep diri remaja Cina Benteng.

\section{Metode Penelitian}

Penelitian ini menggunakan pendekatan penelitian secara kualitatif. Pendekatan kualitatif menurut Robert C. Bogdan dan Steven J. Taylor merupakan metode penelitian dengan menghasilkan data deskriptif yang berbentuk tulisan atau 
lisan dari perilaku yang diamati (Moleong, 2012:4). Penulis menggunakan pendekatan penelitian kualitatif karena sejalan dengan rumusan masalah yang telah ditetapkan yaitu untuk mengetahui gambaran mengenai konsep diri remaja Cina Benteng dan untuk mengetahui faktor apa saja yang mempengaruhi terbentuknya konsep diri remaja Cina Benteng.

Dalam penelitian ini, penulis menggunakan metode penelitian studi kasus. Studi kasus menurut John W. Creswell adalah metode penelitian yang dilakukan dengan cara menyelidiki secara cermat terhadap sebuah program, peristiwa, kegiatan, proses, ataupun sekelompok individu (Lestari, 2013:443). Penulis menggunakan metode penelitian studi kasus karena penulis ingin mengidentifikasi secara mendalam informasi mengenai sebuah fenomena pada kehidupan nyata yang penulis fokuskan pada topik konsep diri remaja Cina Benteng.

Metode pengumpulan data yang dilakukan penulis yaitu wawancara dan studi kepustakaan. Wawancara adalah proses berinteraksi atau kegiatan komunikasi yang bertujuan untuk mendapatkan berbagai informasi secara mendalam tentang sebuah fenomena atau masalah yang dilakukan dengan tanya jawab antara peneliti dengan subyek penelitian. (Mudjia, 2011:2). Pada penelitian ini, penulis melakukan wawancara dengan empat narasumber yang terdiri dari dua key informan (remaja Cina Benteng) dan dua informan (psikolog remaja, budayawan Cina Benteng).

Studi kepustakaan merupakan metode pengumpulan data dengan melakukan analisis terhadap buku, catatan, literatur, dan dokumen yang berkaitan dengan masalah yang akan diteliti (Puspitasari dan Purwoko, 2018:77). Dalam penelitian ini, penulis menggunakan beberapa buku serta jurnal penelitian yang berhubungan dengan Ilmu Komunikasi, yang berkaitan dengan masalah serta metode penelitian sebagai sumber data terpercaya untuk memperkuat penelitian penulis.

\section{Hasil Temuan dan Diskusi}

Menurut Erick Erikson, konsep diri merupakan identitas pada masa remaja, khususnya fokus terhadap cara seseorang dalam menggambarkan mengenai dirinya (Rahmaningsih dan Martani, 2014:179). Terdapat tiga aspek dalam konsep diri menurut Jalaludin Rakhmat yaitu aspek fisik, psikologis, dan sosial (Priyastutik et al., 2019:3).

Aspek fisik yang dimiliki narasumber Angga dan Sasa termasuk ke dalam jenis ras Mongoloid yaitu dengan ciri-ciri warna kulit yang kuning atau sawo matang, postur tubuh yang tidak terlalu besar, rambut yang lurus, dan bentuk hidung yang tidak terlalu mancung. Ciri-ciri tersebut merupakan ciri-ciri yang dimiliki oleh remaja Cina Benteng Angga dan Sasa.

Aspek sosial dari Angga dapat dilihat bahwa dirinya dapat bersosialisasi dan berinteraksi dengan teman sebayanya. Ia merasa diterima dalam lingkungan sosialnya walaupun kadang menerima perkataan yang kurang berkenan dari teman yang berbeda etnis mengenai penampilan fisiknya yang berbeda dengan etnis Cina pada umumnya (wawancara dengan Angga melalui aplikasi Whatsapp pada tanggal 15 November 2020 pukul 18.36 WIB).

Walaupun Angga memeluk agama Katolik, ia tetap mengikuti kegiatan sembahyang yang dilakukan oleh keluarganya. Di rumahnya masih terdapat meja abu untuk melakukan sembahyang bagi leluhurnya. Pada saat perayaan Imlek, Angga masih mengikuti tradisi Cina Benteng yaitu mendatangi satu per satu rumah saudara yang tertua. Apabila mengunjungi rumah saudaranya dan terdapat meja abu maka ia 
diharuskan untuk memberikan penghormatan, berdoa ataupun sembahyang terlebih dahulu. Setelah melakukan sembahyang haruslah saling memberikan salam atau ucapan selamat tahun baru (wawancara dengan Angga melalui aplikasi Whatsapp pada tanggal 13 Desember 2020 pukul 15.00 WIB).

Gambar 1. Remaja Cina Benteng yaitu Angga

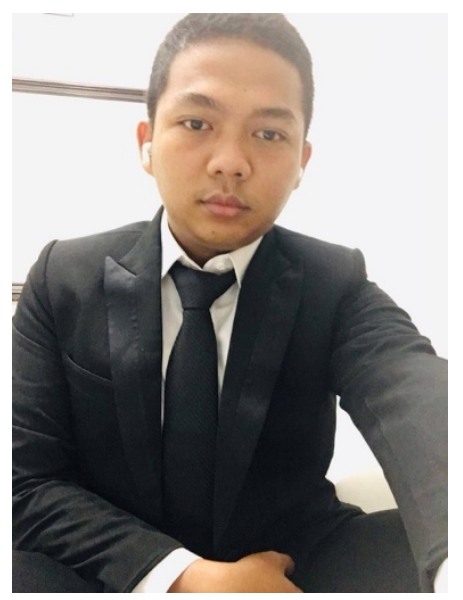

Sumber: Dokumentasi Narasumber Angga pada 26 Agustus 2020

Sedangkan aspek sosial dari narasumber Sasa yaitu ia merasa diterima dalam lingkungan sosial dan sebayanya karena sebagian besar dari teman Sasa merupakan etnis yang sama yaitu Cina Benteng. Oleh karena itu, ia tidak mengalami kendala ataupun kesulitan saat bersosialiasi karena di antara mereka sudah saling mengerti dan memahami (wawancara dengan Sasa melalui aplikasi Whatsapp pada tanggal 15 November 2020).

Hampir sama seperti Angga, Sasa pun masih mengikuti tradisi Imlek Cina Benteng. Namun yang berbeda adalah pada saat malam Imlek, Sasa dan keluarga pergi ke vihara untuk melakukan sembahyang. Pada saat hari Imlek, ia harus melakukan sembahyang pai kepada leluhur dengan menggunakan hio. Setelah itu melakukan salam pai kepada orang tua dan kakak dengan berlutut (wawancara dengan Sasa melalui aplikasi Whatsapp pada tanggal 14 November 13.00 WIB).

Gambar 2. Remaja Cina Benteng yaitu Sasa

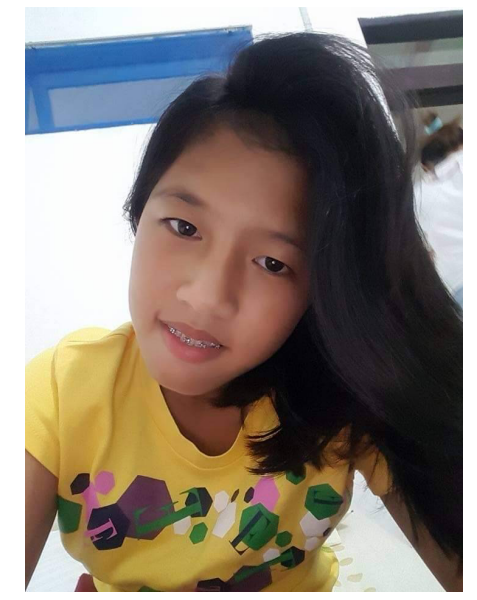

Sumber: Dokumentasi Narasumber Sasa pada 3 Oktober 2020 
Aspek yang terakhir adalah aspek psikologis. Angga dan Sasa memiliki pandangan dan pemikiran yang hampir sama sebagai keturunan etnis Cina Benteng yaitu mereka bangga telah menjadi bagian dari masyarakat Cina Benteng, karena masyarakat Cina Benteng masih memelihara budaya leluhur secara turun temurun seperti tradisi Imlek yang mendatangi rumah-rumah saudara, melakukan penghormatan di meja abu, perayaan Cap Go, Ce It, Ceng Beng, sembayang kue bulan, serta sembayang onde (wawancara dengan Angga melalui aplikasi Whatsapp pada tanggal 15 November 2020 pukul 18.36 WIB dan wawancara dengan Sasa melalui aplikasi Whatsapp pada tanggal 15 November 2020).

Konsep diri menurut Jalaludin Rakhmat dipengaruhi oleh faktor sebagai berikut yaitu:

a. Significant others

Significant others atau yang biasa disebut orang terdekat dalam perkembangan seseorang yang berpengaruh terhadap tingkah laku, pikiran, dan perasaan. Significant others meliputi orang tua, saudara, kerabat serta orang lain yang tinggal dalam satu rumah.

b. Affective others

Affective others merupakan orang lain yang memiliki ikatan batin dengan seseorang yang kemudian akan membentuk konsep diri orang tersebut. Misalnya mendapatkan pujian dari orang lain membuat individu memiliki pandangan yang positif, akan tetapi jika mendapatkan sindiran individu menjadi memiliki pandangan negatif.

c. Reference Grup (Kelompok Rujukan)

Dalam lingkungan masyarakat terdapat sebuah organisasi kecil yang biasa bernama rukun tetangga, rukun warga atau perkumpulan mahasiswa dan lainlain yang setiap kelompok tersebut memiliki aturan dan nilai tertentu. Kelompok - kelompok tersebut akan mempengaruhi tingkah laku seseorang sesuai dengan ciri - ciri kelompok tersebut (Indrawati et al, 2016:3).

Hal ini selaras dengan hasil wawancara dengan Angga, karena ia lebih sering berinteraksi dengan teman-temannya dibandingkan dengan orang tua atau keluarganya. Angga merasa tidak dekat dengan keluarganya dan merasa kurang nyaman untuk bercerita kepada keluarganya. Hal tersebut sesuai dengan pernyataan dari Buhrmester dalam sumber yang sama, bahwa remaja akan lebih terbuka kepada teman-temannya terutama mengenai hal-hal intim ataupun informasi yang bersifat pribadi (Dinata et.al, 2019:329). Oleh karena itu Angga lebih dekat dengan temantemannya untuk bercerita ataupun bermain. Ia biasa menghabiskan waktu untuk berkeliling kota Jakarta menggunakan sepeda motor bersama-sama. Walaupun ia tidak dekat dengan keluarganya, pada saat sedang berkumpul bersama Angga berusaha untuk terbuka dan membaur dengan keluarganya.

Menurut Sasa, ia lebih nyaman dan senang jika berinteraksi dengan keluarganya. Hal tersebut terjadi karena ia lebih sering menghabiskan waktu untuk berkumpul bersama dengan keluarga besarnya. Terlebih orang tuanya yang mempunyai usaha keluarga yaitu penyewaan Gambang Kromong. Adanya usaha tersebut membuat Sasa dan keluarga sering berkumpul untuk mengikuti kegiatan pementasan Gambang Kromong miliknya.

Namun ada beberapa hal yang menurutnya lebih nyaman jika dilakukan dengan teman sebayanya. Contohnya adalah ketika ia ingin bercerita tentang orang yang disukai maka ia akan lebih memilih untuk bercerita kepada temannya dibanding kepada orang tuanya. Akan terasa canggung jika harus bercerita mengenai hal 
tersebut kepada orang tuanya (wawancara dengan Sasa melalui aplikasi Whatsapp pada tanggal 15 November 2020).

\section{Simpulan}

Konsep diri terbagi menjadi tiga aspek yaitu aspek fisik, sosial, dan psikologis. Aspek fisik dari remaja Cina Benteng termasuk ke dalam golongan ras mongoloid karena memiliki warna kulit yang cenderung gelap dan matanya yang tidak sipit. Hal tersebut termasuk ciri-ciri dari ras mongoloid.

Dalam aspek sosial, remaja Cina Benteng pernah mengalami perundungan secara verbal mengenai fisik yang dilakukan oleh teman yang berbeda etnis. Namun adapula remaja Cina Benteng Firenza yang tidak mengalami kendala pada saat bersosialisasi. Kedua remaja Cina Benteng masih mengikuti beberapa tradisi dari Cina Benteng seperti Imlek dan ritual sembayang yang dilakukan pada saat perayaan tertentu. Walaupun keturunan etnis Cina, remaja Cina Benteng tidak bisa menggunakan bahasa Mandarin.

Terakhir adalah aspek psikologis. Kedua remaja tersebut merasa bangga menjadi keturunan Cina Benteng karena mereka menganggap bahwa Cina Benteng memiliki banyak kebudayaan yang masih dilestarikan hingga saat ini.

\section{Ucapan Terima Kasih}

Pertama penulis ingin mengucapkan terima kasih kepada Tuhan Yang Maha Esa karena berkat-Nya penulis dapat menyelesaikan skripsi ini, kepada key informan dan informan yang sudah meluangkan waktunya, serta kepada orang tua, adik-adik, dan juga teman-teman terdekat yang selalu memberikan doa serta dukungannya.

\section{Daftar Pustaka}

Anisa, Marsela Fitri dan Budi Sulistyo. (2012). Pengembangan Sejarah dan Budaya Kawasan Cina Benteng Kota Lama, Tangerang. Jurnal Planesa. 3 (2). 95101.

Berndt, T. J. (2007). Friendship Quality And Social Development. Current Directions in Psychological Science, 11, 7-10.

Databoks. (1 Oktober 2020). 1,2 Persen Penduduk Indonesia Adalah Etnis Cina. Diakses dari https://databoks.katadata.co.id/datapublish/2017/01/28/283persen penduduk-indonesia-adalah-etnis-cina

Dewiyanto, Putri, dan Suzy S Azeharie. (2018). Studi Komunikasi Ritual Teh Pai Pada Pernikahan Tionghoa Cina Benteng di Tangerang. Jurnal Komunikasi. 2 (2). 524-531.

Gumulya, Jessica dan Mariyana Widiastuti. (2013). Pengaruh Konsep Diri Terhadap Perilaku Konsumtif Mahasiswa Univeritas Esa Unggul. Jurnal Psikologi. 11 (1). 50-65.

Hendriyani, Rulita, Tiara Devi Farisa, dan Sri Maryati Deliana. (2013). FaktorFaktor Penyebab Perilaku Seksual Menyimpang Pada Remaja Tunagrahita SLB N Semarang. Developmental and Clinical Psychology. 2(1). 26-32.

NTT Pertama, Sulut Peringkat Dua Kerukunan Umat Beragama. (2017, Januari 05). Retrieved Juni 02, 2017, from Manado Post Online: 
http://manadopostonline.com/read/2017/01/05/NTT-Pertama-SulutPeringkat-Dua-Kerukunan-Umat-Beragama/19719

Oktavianti, Roswita. (2012). Komunikasi Massa Sebuah Pengantar. Jakarta: Untar Press.

Paramita, S., \& Sari, W. P. (2016). Komunikasi Lintas Budaya dalam Menjaga Kerukunan antara Umat Beragama di Kampung Jaton Minahasa. Jurnal Pekommas, 1(2), 153-166.

Priyastutik, S., Suhendri, H., \& Kasyadi, S. (2018). Pengaruh Kemandirian Dan Konsep Diri Terhadap Pemecahan Masalah Matematika Siswa. JKPM (Jurnal Kajian Pendidikan Matematika) 4 (1). 1-10.

Purnama, T. J. (2014). Strategi Komunikasi. Jurnal Komunikasi, 07,1, 7-10.

Soekanto, Soerjono. (2012). Sosiologi suatu pengantar (Edisi 7). Jakarta: PT. Raja Grafindo Persada.

Suhada, A. (2017, April 23). Jusuf Kalla Buka Acara Pekan Kerukunan Umat Beragama di Manado. Retrieved Juni 02, 2017, from Tempo Online: https://nasional.tempo.co/read/news/2017/04/23/078868781/jusuf-kalla-bukaacara-pekan-kerukunan-umat-beragama-di-manado

Samovar, L. A., Porter, R. A., \& McDaniel, E. R. (2010). Komunikasi Lintas Budaya (7th ed.). Jakarta, Indonesia: Salemba Humanika.

Tamburian, H.H Daniel. (2018). Komunikasi Lintar Budaya Masyarakat Dayak Dalam Menjaga Kerukunan Hidup Umat Beragama. Jurnal Komunikasi. 10 (1). 77-86. 